\title{
Spatial and temporal patterns of zooplankton biomass across the Gulf Stream
}

\author{
Stuart K. Allison* \& Karen F. Wishner \\ Graduate School of Oceanography, University of Rhode Island, Narragansett, Rhode Island 02882, USA
}

\begin{abstract}
Zooplankton biomass in the upper $200 \mathrm{~m}$ of the Gulf Stream was sampled bimonthly for a year from November 1981 to November 1982 and again in May 1983 along a 9 station transect crossing the Gulf Stream east of Cape Hatteras. Vertically stratified sampling of zooplankton biomass to $1000 \mathrm{~m}$ depth both day and night at 3 of the stations was done on 2 of the cruises. Concurrent hydrographic measurements and in situ water velocity profiles were also obtained. Zooplankton biomass tends to be highest in the Slope Water, intermediate at the northern boundary (north wall) of the Gulf Stream, and lowest in the central part of the Stream and Sargasso Sea. The north wall of the Gulf Stream is a frontal region, where zooplankton and phytoplankton biomass can sometimes be much higher than in the rest of the Stream. Zooplankton biomass is highest in the upper $100 \mathrm{~m}$ of the water column both day and night, but there is sometimes also a deep biomass maximum below $400 \mathrm{~m}$ during the day. Between 11 and $44 \%$ of the total zooplankton biomass in the upper $1000 \mathrm{~m}$ migrates up into the top $200 \mathrm{~m}$ at night. Zooplankton biomasses in the upper $200 \mathrm{~m}$ in the Slope Water, Gulf Stream, and north wall of the Gulf Stream show an apparent seasonal pattern with maximum abundances in late spring and early summer and a minimum in the autumn. No significant seasonality of zooplankton biomass is apparent in the Sargasso Sea samples. The amount and direction of transport of zooplankton biomass by the Gulf Stream varies with horizontal and vertical location in the Stream and is affected by the diel vertical migration of the zooplankton.
\end{abstract}

\section{INTRODUCTION}

In the northwestern Atlantic Ocean, the Gulf Stream functions as a boundary between cool water temperate communities and warm water subtropical communities (Grice \& Hart 1962, Backus et al. 1977, Angel 1979). It also serves as a vehicle for long distance dispersal downstream (Scheltema 1971) and between-community mixing cross-stream (Ring Group 1981, Wishner \& Allison in press). Although the northwestern Atlantic is one of the better studied open ocean regions of the world, and recently Gulf Stream rings and eddies have been intensively analyzed (e.g. Ring Group 1981, Paffenhöfer et al. 1984, Wiebe et al. 1985), relatively little is known of the detailed biology of the Gulf Stream itself, especially offshore and downstream of Cape Hatteras.

Several studies have examined the zooplankton biomass of the northwestern Atlantic (Clarke 1940, Moore 1949, Fish 1954, Bsharah 1957, Menzel \& Ryther

\footnotetext{
- Present address: Department of Zoology, University of California, Berkeley, California 94720, USA
}

1961, Grice \& Hart 1962, Bé et al. 1971, Deevey 1971, Deevey \& Brooks 1971, Ortner et al. 1978, 1980, Roman et al. 1985, Wiebe et al. 1985), but most have concentrated on the Slope Water, Sargasso Sea, or Gulf Stream rings. Although these workers sampled with different nets, mesh sizes, and sampling strategies, making it difficult to compare absolute biomass values between studies, patterns of distribution may be compared. In these reports, biomasses in the Slope Water are higher and usually show stronger seasonality than those from the Sargasso Sea. Grice \& Hart (1962), Bé et al. (1971), and Wiebe et al. (1985) included a few zooplankton biomasses from the Gulf Stream, and Bsharah (1957) looked at the zooplankton biomass in the Florida Straits region. However, none of these previous studies considered the details of the crossstream distribution of zooplankton biomass in relation to the physical structure of the Gulf Stream.

The Gulf Stream is a system dominated by physical forces, and complex interactions between biological and physical processes affect the distribution of zooplankton species inhabiting the Stream (Stepien 1980, Wishner \& Allison in pressj. The northern boundary, or 
north wall, of the Gulf Stream downstream and offshore of Cape Hatteras, is a sharp frontal region, while the southern edge is a zone of gradual change to the Sargasso Sea (Stommel 1965). Near the surface, temperatures are warm and isotherms parallel the surface, but below about $20^{\circ} \mathrm{C}$, isopycnals and isotherms, as well as isolines of the distributions of many other physical parameters, slope downward from north to south (Stommel 1965). For example, during September 1982 , the $15^{\circ} \mathrm{C}$ isotherm changed from $220 \mathrm{~m}$ depth at the north wall to $540 \mathrm{~m}$ depth at the southern edge, about $40 \mathrm{~km}$ away (Wishner \& Allison in press). Downstream and cross-stream water velocities also vary greatly with depth and location across the Stream and over time (Halkin 1984, Halkin \& Rossby 1985). More complete descriptions of the general physical oceanography of the Gulf Stream may be found in Stommel (1965), Worthington (1976), Fofonoff (1981), and Shaw \& Rossby (1984).

This paper examines the horizontal, vertical, and temporal distributions of zooplankton biomass within and across the Gulf Stream over a year in order to provide a broad view of spatial and temporal abundance patterns. The distributions of individual copepod species from the same sampling program are presented in Wishner \& Allison (in press).

\section{MATERIALS AND METHODS}

Data collection. The data were collected on 7 cruises aboard the R/V Endeavor and R/V Cape Hatteras in the Gulf Stream region east of Cape Hatteras. The cruises occurred bimonthly from November 1981 to November 1982, with an additional cruise in May 1983, as part of an intensive multiyear study of the velocity field and hydrography of the Stream by H. T. Rossby (University of Rhode Island). Biological sampling was conducted on an ancillary basis during the cruises and interspersed with the physical measurements. Cruise dates and other sampling information are summarized in Table 1.

Zooplankton samples were collected at a set of 9 stations positioned $20 \mathrm{~km}$ apart perpendicular to the mean direction of the flow of the Stream along a transect centered at $36^{\circ} \mathrm{N}, 73^{\circ} \mathrm{W}$ (Fig. 1). The stations are located such that if the Gulf Stream is in an average position, the northern stations will be in the Slope Water, the central stations in the Stream, and the southern stations in the Sargasso Sea (Halkin 1984).

During all cruises except May 1983, 2 replicate zooplankton samples were collected at each station with a $0.65 \mathrm{~m}$ diameter net (202 $\mu \mathrm{m}$ mesh) towed obliquely through the upper $200 \mathrm{~m}$ of the water column. Each tow filtered 100 to $260 \mathrm{~m}^{3}$ of water. Samples were
Table 1. Cruise and sampling information

\begin{tabular}{|c|c|c|}
\hline Cruise & Date & $\begin{array}{l}\text { Zooplankton } \\
\text { sampling }\end{array}$ \\
\hline Endeavor 77 & Nov 7-17, 1981 & $\begin{array}{l}65 \mathrm{~cm} \text { open net } \\
0-200 \mathrm{~m} \text { oblique }\end{array}$ \\
\hline Endeavor 79 & $\operatorname{Jan} 27-F e b 4,1982$ & $\begin{array}{l}65 \mathrm{~cm} \text { open net } \\
0-200 \mathrm{~m} \text { oblique }\end{array}$ \\
\hline Endeavor 81 & Mar 12-20, 1982 & $\begin{array}{l}65 \mathrm{~cm} \text { open net } \\
0-200 \mathrm{~m} \text { oblique }\end{array}$ \\
\hline Cape Hatteras 12 & May 9-19, 1982 & $\begin{array}{l}65 \mathrm{~cm} \text { open net } \\
0-200 \mathrm{~m} \text { oblique }\end{array}$ \\
\hline Cape Hatteras 16 & Jul 9-18, 1982 & $\begin{array}{l}65 \mathrm{~cm} \text { open net } \\
0-200 \mathrm{~m} \text { oblique }\end{array}$ \\
\hline Endeavor 89 & Sep 6-16, 1982 & $\begin{array}{l}\quad 65 \mathrm{~cm} \text { open net } \\
\text { 0-200 m oblique } \\
\text { MOCNESS } \\
0-400 \mathrm{~m} \text { all stations } \\
0-200 \mathrm{~m} \text { intensive } \\
0-1000 \mathrm{~m} \text { intensive }\end{array}$ \\
\hline Endeavor 92 & Nov $20-29,1982$ & $\begin{array}{l}65 \mathrm{~cm} \text { open net } \\
0-200 \mathrm{~m} \text { oblique }\end{array}$ \\
\hline Endeavor 99 & May 9-25, 1983 & $\begin{array}{l}\text { MOCNESS } \\
0-400 \mathrm{~m} \text { all stations } \\
0-200 \mathrm{~m} \text { intensive } \\
0-1000 \mathrm{~m} \text { intensive }\end{array}$ \\
\hline
\end{tabular}

preserved in $4 \%$ buffered Formalin. The biomass of the zooplankton samples was measured by displacement volume (Beers 1976) 8 to $10 \mathrm{wk}$ after collection, after first removing large gelatinous zooplankton and fish.

During September 1982 and May 1983, vertically stratified zooplankton samples were obtained with a $1 \mathrm{~m}^{2}$ MOCNESS (333 $\mu \mathrm{m}$ mesh) (Wiebe et al. 1976). This opening-closing net system collects 9 sequential samples along with in situ environmental information (depth, temperature) and sampling data (volume filtered, net angle). Data from the MOCNESS was processed and stored at sea on a Hewlett-Packard 85 computer. Each net in a MOCNESS tow filtered from 300 to $1000 \mathrm{~m}^{3}$ of water. Samples were preserved in $4 \%$ buffered Formalin, and biomasses were determined as previously described.

The regular 9 stations of the Gulf Stream transect were sampled with the MOCNESS in $50 \mathrm{~m}$ intervals from $400 \mathrm{~m}$ to the surface. In addition, 3 of the transect stations were sampled intensively. These stations, 20 to $40 \mathrm{~km}$ apart, were located at the north wall of the Stream $\left(15^{\circ} \mathrm{C}\right.$ isotherm at $200 \mathrm{~m}$ and surface velocity $>100 \mathrm{~cm} \mathrm{~s}^{-1}$ ), the warm high velocity core (surface temperature $>27.5^{\circ} \mathrm{C}$ and surface velocity $>100 \mathrm{~cm}$ $\mathrm{s}^{-1}$ ), and the southern edge of the Stream (surface velocity 40 to $100 \mathrm{~cm} \mathrm{~s}^{-1}$ ). At each of these stations, MOCNESS tow series, centered at noon and midnight, were conducted, with each series consisting of a deep and shallow sample set. The deep tow collected sam- 




Fig. 1. Location of the transect. The short ticks are the stations arranged in numerical order from P0 at the southern end to P8 at the northern end. The longer lines perpendicular to the transect are the positions of the north wall of the Gulf Stream during each cruise, identified by different symbols

ples from $1000 \mathrm{~m}$ to the surface, in intervals of $150 \mathrm{~m}$ from 1000 to $400 \mathrm{~m}$ and in intervals of $100 \mathrm{~m}$ from $400 \mathrm{~m}$ to the surface. The shallow tow collected samples from $200 \mathrm{~m}$ to the surface, in intervals of $25 \mathrm{~m}$. The MOCNESS was towed into the flow of the Stream to maintain a constant cross-stream location.

Expendable bathythermographs (XBTs), deployed to $750 \mathrm{~m}$, were used to determine the location of each station relative to the position of the Gulf Stream. In situ temperature and horizontal velocity profiles to a depth of at least $2000 \mathrm{~m}$ were obtained at each station with a cast of a free vehicle Pegasus velocity profiler (Spain et al. 1981) by H. T. Rossby and his group (Halkin \& Rossby 1985). Infrared satellite imagery of sea surface temperature, from the Remote Sensing Center at the Graduate School of Oceanography of the University of Rhode Island, was also used to determine the location and structure of the Stream. Additional physical and biological measurements from the 3 intensive stations in September 1982 are presented in Wishner \& Allison (in press).

Data analysis. All data are analyzed relative to natural Gulf Stream coordinates, with axes parallel to and perpendicular to the mean direction of downstream flow (Halkin 1984, Halkin \& Rossby 1985). For each cruise, the angle at which the mean direction of Stream flow intersects the transect is measured, and the relative Stream positions of each station are then rotated into a Stream coordinate system. Therefore, samples collected at the same cross-stream location on different cruises are comparable, even though their geographic positions may differ. Fig. 1 shows the actual position of the north wall of the Gulf Stream in relation to the geographically fixed transect stations for each of the cruises.

For each cruise, the zooplankton biomass values are divided into 4 cross-stream regions: the Slope Water, the north wall of the Gulf Stream, the Gulf Stream proper, and the Sargasso Sea. Slope Water stations, which have low surface velocities $\left(<30 \mathrm{~cm} \mathrm{~s}^{-1}\right)$, are defined as those northwest of the location at which the $15^{\circ} \mathrm{C}$ isotherm is $200 \mathrm{~m}$ deep. The north wall is the single station in each cruise where the $15^{\circ} \mathrm{C}$ isotherm is closest to $200 \mathrm{~m}$ deep. Surface downstream velocity is high at this station, usually greater than $100 \mathrm{~cm} \mathrm{~s}^{-1}$. The Gulf Stream proper is the region in which the $15^{\circ} \mathrm{C}$ isotherm continues to deepen from north to south, and surface downstream velocities range from 40 to $200 \mathrm{~cm} \mathrm{~s}^{-1}$. The Sargasso Sea is the region in which the $15^{\circ} \mathrm{C}$ isotherm levels out at about $650 \mathrm{~m}$ depth and where surface downstream velocities are less than $30 \mathrm{~cm} \mathrm{~s}^{-1}$.

Because of the constraints of coordinating the biological sampling with the main physical oceanography program, the local time of sampling with the oblique tows at each station is variable. To control for possible diel effects (such as higher nighttime biomasses), the day and night oblique samples are treated separately, and dawn and dusk samples are excluded from the analyses. Dawn is defined as the period of time from $2 \mathrm{~h}$ before until $2 \mathrm{~h}$ after sunrise, and dusk is the period from $2 \mathrm{~h}$ before until $2 \mathrm{~h}$ after sunset. The times of sunrise and sunset for a particular date and geographic position are from The Nautical Almanac (1981, 1982, 1983).

To determine if there are significant differences in zooplankton biomass between the regions, the biomass values from the oblique tows are treated as follows. First, relative biomasses are calculated by dividing each measurement by the median Sargasso Sea biomass value for that cruise. This procedure serves to highlight the overall relations between the 4 areas by reducing the effects of any seasonal changes in absolute abundances. Relative biomasses for the day and night samples are calculated separately, since differences between day and night biomasses at a single station can be of the same magnitude as differences between areas across the Stream during a particular cruise. A Kruskall-Wallis test (Sokal \& Rohlf 1981) is used to compare relative biomasses from the 4 regions.

To determine whether there is evidence for seasonal variability within each region, the following procedure is used. Biomass anomalies, the difference between a particular biomass value and the median value of all 


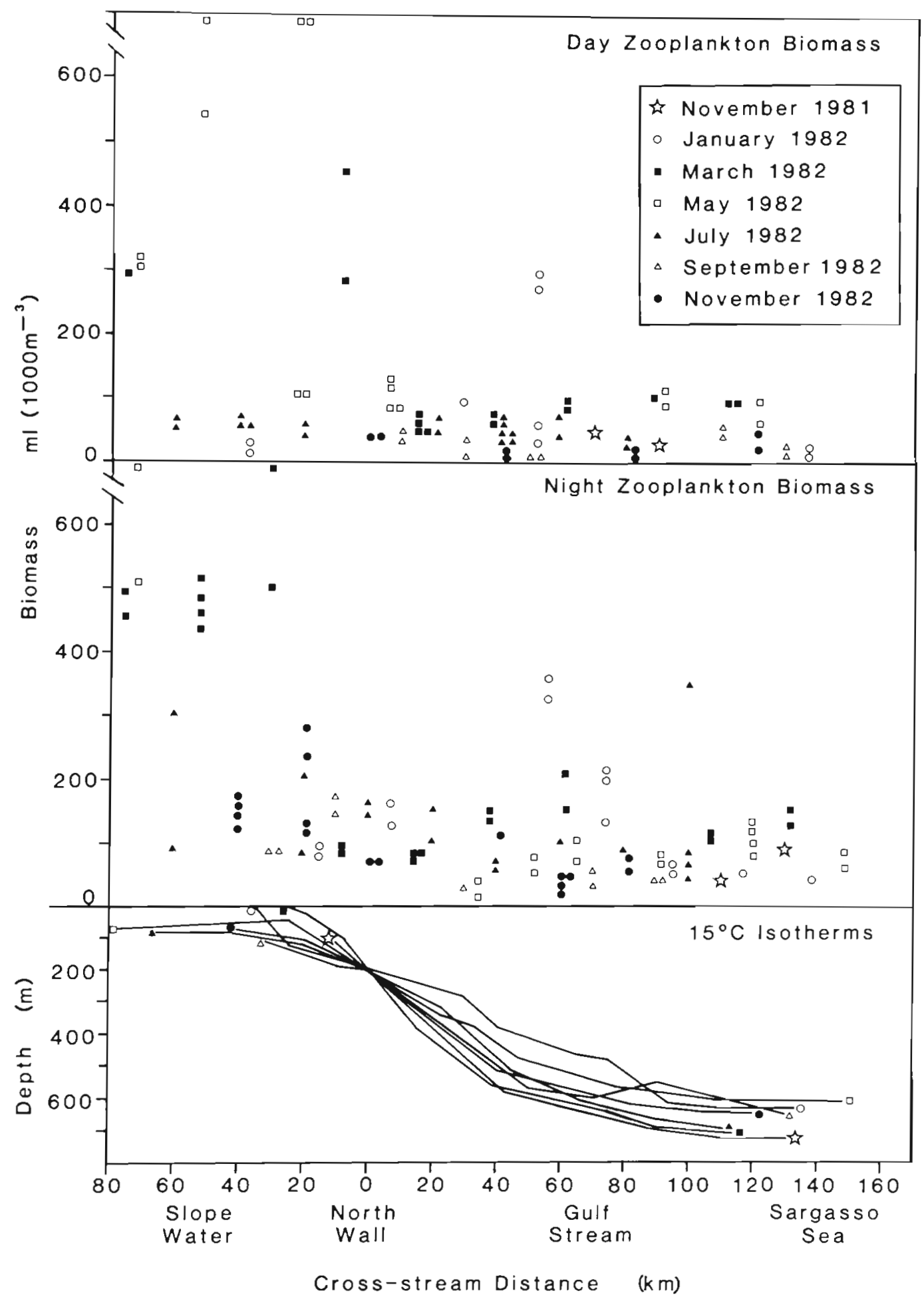

Fig. 2. Day and night biomasses from the oblique tows in the upper $200 \mathrm{~m}$ along the transect. The position of the north wall of the Gulf Stream is used as the reference point, and the stations are arrayed relative to the north wall by aligning the $15^{\circ} \mathrm{C}$ isotherm for each cruise so that the geographic location where this isotherm is at $200 \mathrm{~m}$ depth (defined as the north wall) intersects for all cruises. Biomasses (upper panels) and the depths of the $15^{\circ} \mathrm{C}$ isotherms (lower panel) are identified by different symbols for each 
Table 2. Median ratios of the biomass in each region relative to that of the Sargasso Sea. The lines group areas that are not significantly different. The MOCNESS values are the integrated water column biomasses and were not tested because of the small sample size. N: not sampled

\begin{tabular}{|lllllc|}
\hline \multicolumn{1}{|c}{$\begin{array}{c}\text { Tow } \\
\text { series }\end{array}$} & $\begin{array}{c}\text { Time } \\
\text { of day }\end{array}$ & $\begin{array}{c}\text { Slope } \\
\text { water }\end{array}$ & $\begin{array}{c}\text { North } \\
\text { wall }\end{array}$ & $\begin{array}{c}\text { Gulf } \\
\text { Stream }\end{array}$ & $\begin{array}{c}\text { Sar- } \\
\text { gasso } \\
\text { Sea }\end{array}$ \\
\hline $200 \mathrm{~m}$ & Day & 5.8 & 2.4 & 1.7 & 1 \\
oblique & Night & $\underline{2.4}$ & $\underline{1.4}$ & 0.8 & 1 \\
$400 \mathrm{~m}$ & Day & 4.4 & 2.1 & 1.7 & 1 \\
MOCNESS & Night & 1.5 & $\mathrm{~N}$ & 0.5 & 1 \\
$1000 \mathrm{~m}$ & Day & $\mathrm{N}$ & 1.1 & 0.9 & 1 \\
MOCNESS & Night & $\mathrm{N}$ & 1.5 & 1.1 & 1 \\
\hline
\end{tabular}

day or night biomass estimates for that region, are calculated for each oblique tow sample. Anomalies are derived separately for day and night samples, to account for diel differences. All anomalies within a particular region (combined day and night samples) are tested with a Kruskall-Wallis test (Sokal \& Rohlf 1981) for the existence of significant differences between cruises.

\section{RESULTS}

\section{Horizontal patterns}

All zooplankton biomasses collected in the $200 \mathrm{~m}$ oblique tows from November 1981 to November 1982 are graphed together in Fig. 2, and a listing of the values may be obtained from the authors. Median ratios between areas are presented in Table 2 . Biomasses from the night samples show significant overall differences among regions (Kruskall-Wallis test, $p<0.05$ ) (Table 2). The Slope Water biomass is significantly greater than that of both the Gulf Stream and Sargasso Sea (Tukey-Kramer a posteriori tests of minimum significant difference, $p<0.05$; Sokal \& Rohlf 1981). Biomass at the north wall is intermediate between the Slope Water and Gulf Stream, but not significantly different from any other region. The Gulf Stream and Sargasso Sea are also not significantly different. Biomasses from the daytime oblique tows and the MOCNESS tows (Table 2; Fig. 3) have similar trends.

The north wall region frequently shows increased zooplankton concentrations relative to the Gulf Stream and Sargasso Sea (Fig. 2), although it is not significantly different from other areas in the total sample set.
Fig. 3. Vertical profiles of day (light tone) and night (dark tone) biomass concentrations from MOCNESS tows. $\mathrm{N}$ : north wall station; C: central core station; $\mathrm{S}$ : southern edge of the Stream; $x$ : missing sample. Biomasses are from coarse-scaled tows below $200 \mathrm{~m}$ and from fine-scaled tows above $200 \mathrm{~m}$. Dotted line in May 1983 day graph is biomass from 0 to $100 \mathrm{~m}$ in the coarse sampling Integrated water column biomasses for each tow are given at the base of its profile, and the thick horizontal line through each profile shows depth of $50 \%$ level of cumulative biomass
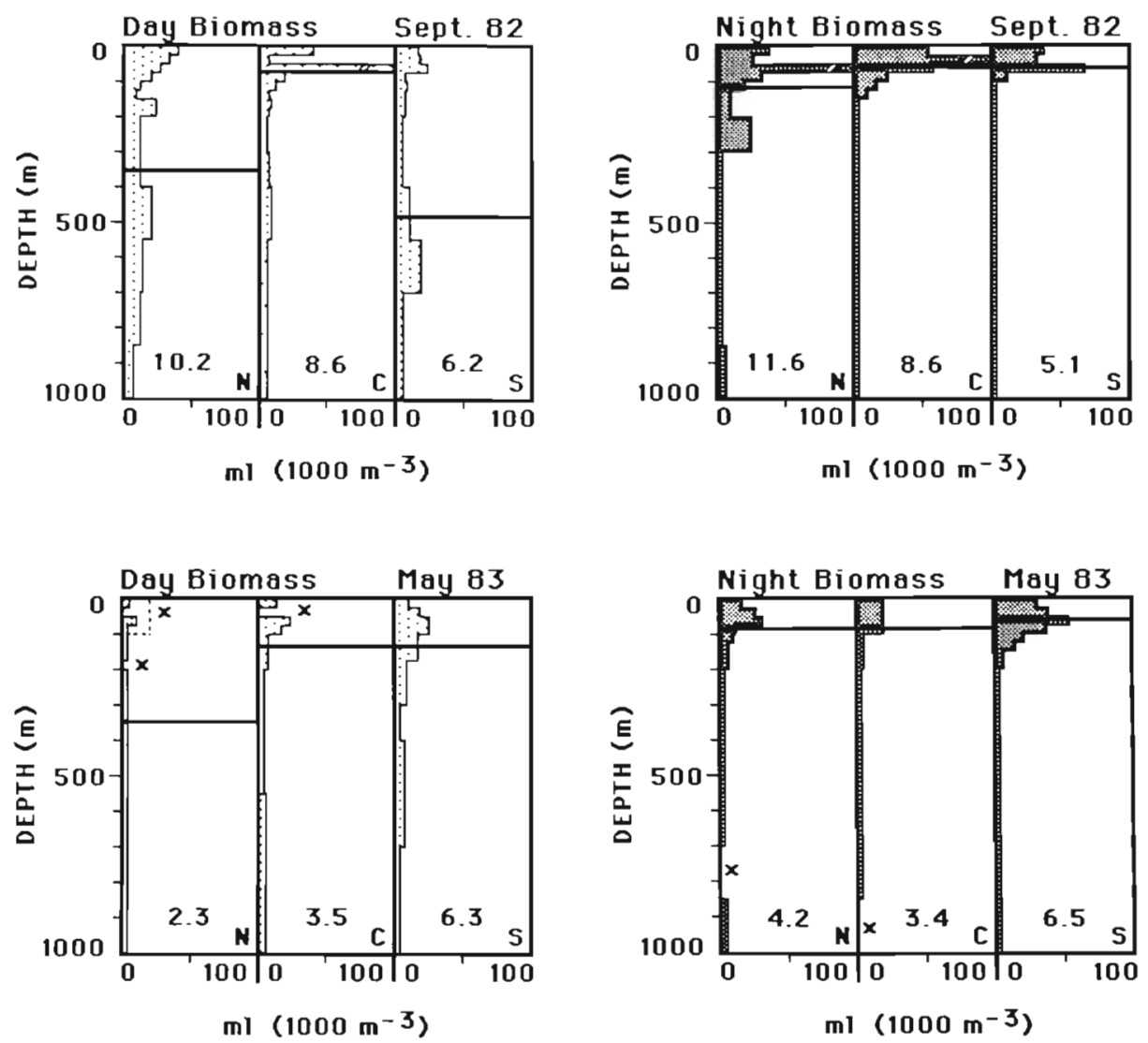
For example, in March, July, September, and November 1982 and May 1983, biomasses at the north wall were 1.5 to 6 times greater than in the Gulf Stream or Sargasso Sea. During March 1982, the highest zooplankton biomasses of the entire transect occurred here. This biomass peak was accompanied by high concentrations of the diatom Thalassiosira partheneia. During May 1983, there were large concentrations of the salp Salpa fusiformis and the ctenophore Pleurobrachia pileus at the north wall and Slope Water stations, but other smaller zooplankton were unusually low in abundance.

\section{Vertical patterns and diel migration}

The highest zooplankton biomass concentrations [ml $\left.\left(1000 \mathrm{~m}^{-3}\right)\right]$ occur in the upper $100 \mathrm{~m}$ of the water column, especially at night (Fig. 3). Abundance peaks can be as narrow as a single $25 \mathrm{~m}$ sampling interval. During the day, there may be an additional biomass peak at about 400 to $700 \mathrm{~m}$. Biomasses at $1000 \mathrm{~m}$, the deepest sampling interval, are about an order of magnitude less than those near the surface.

The integrated water column biomasses $\left(\mathrm{ml} \mathrm{m} \mathrm{m}^{-2}\right.$ from 0 to $1000 \mathrm{~m}$ ) are similar in the day and night in the

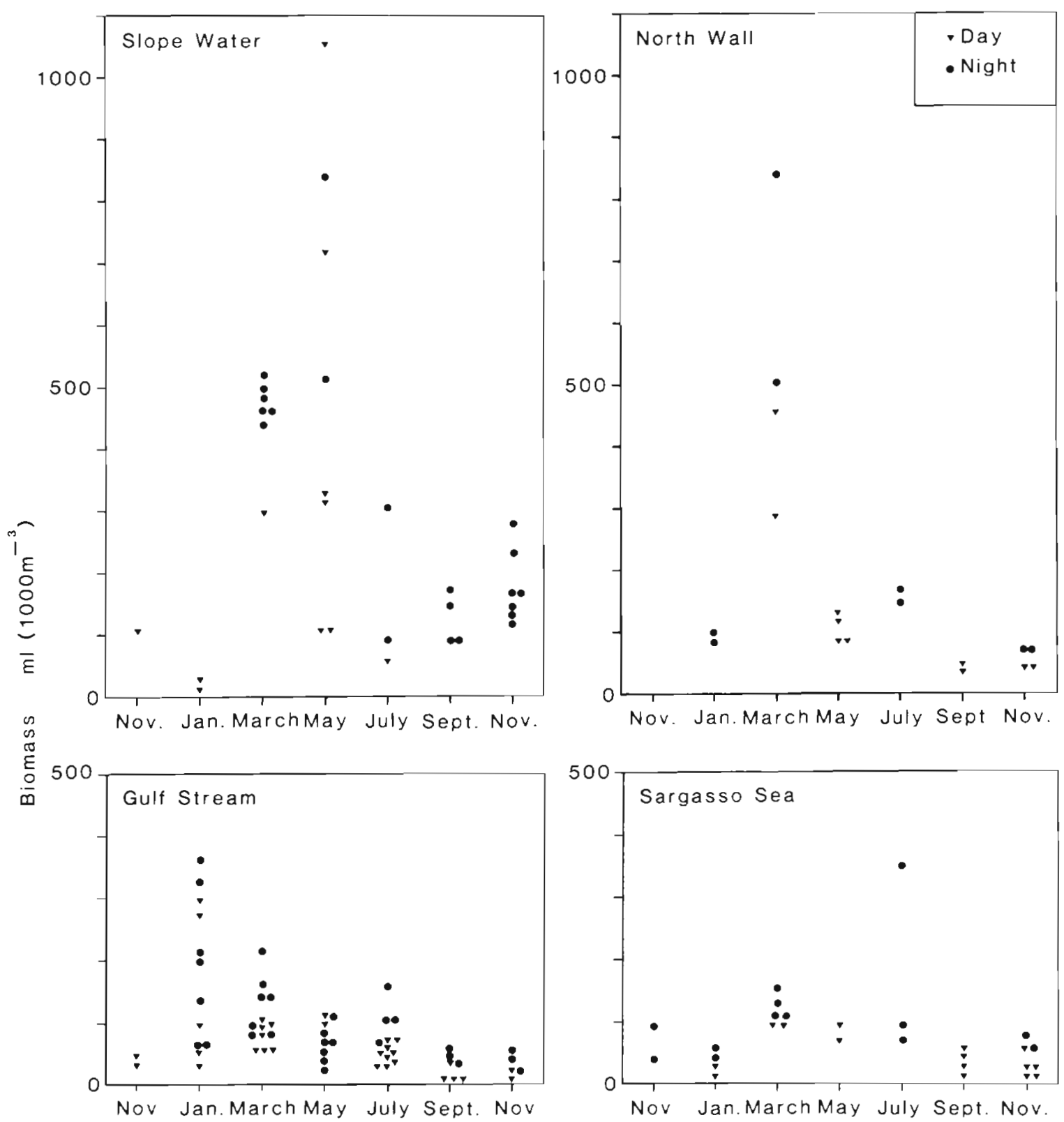

Fig. 4. Seasonal patterns of biomass concentration in each region from the $200 \mathrm{~m}$ oblique tows. Day and night values are shown by different symbols 
warm core and southern edge (though not at the north wall), but the depth marking $50 \%$ of the cumulative water column biomass shoals from day to night (Fig. 3). From 11 to $44 \%$ of the integrated water column biomass appears to migrate up into the top $200 \mathrm{~m}$ at night. About 28 to $69 \%$ of the integrated water column biomass occurs in the upper $200 \mathrm{~m}$ during the day in these transects, and 56 to $88 \%$ is there at night. The mean day-night difference in the proportion of total water column biomass present in the upper $200 \mathrm{~m}$ is lowest at the warm core (11\% change) and highest at the southern edge ( $35 \%$ change). Biomass concentration $\left[\mathrm{ml}\left(1000 \mathrm{~m}^{-3}\right)\right]$ in the upper $200 \mathrm{~m}$ is 1.3 to 3.5 times higher at night than during the day in all regions (all sampling types combined), and day and night biomasses from the $200 \mathrm{~m}$ oblique tows are significantly different in the Gulf Stream and Sargasso Sea (Wilcoxen 2-sample tests, $\mathrm{p}<0.05$; Sokal \& Rohlf 1981).

\section{Seasonal patterns}

The monthly patterns of biomass from the shallow oblique tow series, separated by region, are shown in Fig. 4. The Slope Water, north wall, and central Gulf Stream all show significant variability between cruises (Kruskall-Wallis tests, $p<0.05$ ), while the Sargasso Sea does not. In these regions, the highest biomasses occur in the spring and the lowest in autumn. The spring maximum occurs earliest in the Gulf Stream, the most southern of these 3 regions, and progressively later to the north. January is the month of maximum biomass in the Gulf Stream, March at the north wall, and May in the Slope Water. September is the time of minimum biomass in all 3 regions. The ratio of maximum to minimum biomass (using monthly medians) is 5 in the Slope Water, 10 at the north wall, and 6 in the Gulf Stream.

The 2 MOCNESS sampling series were separated by about $8 \mathrm{mo}$. Consequently, it is not possible to use them to examine seasonality directly, but they can be compared with patterns from the year-long $200 \mathrm{~m}$ oblique tow series. During September 1982, both types of gear were used and show similar cross-stream biomass patterns. (Biomass concentrations from the oblique tows average 1.7 times greater than those from the MOCNESS tows at the same depths, and thus absolute biomass values from these 2 different nets are not directly comparable.)

In September 1982, the integrated total water column zooplankton biomasses $\left(\mathrm{ml} \mathrm{m}^{-2}\right)$ from the MOCNESS tows are 2.5 to 4.5 times greater than in May 1983 (except on the southern edge of the Stream) (Fig. 3). This is opposite to the pattern from the previous year's bimonthly oblique tow series, in which Sep- tember 1982 biomasses are among the lowest observed, while May 1982 biomasses are the highest (Fig. 4). In May 1983, dense aggregations of the salp Salpa fusiformis and the ctenophore Pleurobrachia pileus occur in the upper $100 \mathrm{~m}$ at the Slope Water and north wall stations. These large gelatinous animals are excluded from the measurements of displacement volume, and thus from the biomass estimates, which consider only the smaller zooplankton. The biomass of the smaller zooplankton is therefore much reduced in May 1983 compared to May of the previous year.

\section{DISCUSSION}

The high percentage of water column biomass occurring in the upper $200 \mathrm{~m}$ implies that the year-long series of oblique tows (from the upper $200 \mathrm{~m}$ ) sampled a substantial portion of the total water column biomass. Biomass variations detected by these tows, therefore, are probably also representative of changes in overall water column biomass.

The trend of high biomasses in the Slope Water and low biomasses in the Sargasso Sea agrees with results of previous studies of the northwestern Atlantic (summarized in Table 3), which have found zooplankton biomass to be 1 to 15 times greater in the Slope Water than in the Gulf Stream or Sargasso Sea. No previous studies, however, have differentiated between the various regions of the Gulf Stream itself.

The north wall of the Gulf Stream, for example, is often a location of elevated concentrations of zooplankton biomass in this sample set. During 5 of the 8 cruises, zooplankton biomass was higher at the north wall than in the Gulf Stream core or Sargasso Sea; during one cruise, the north wall biomass was higher than even the Slope Water biomass. The biomass maxima from the upper $200 \mathrm{~m}$ occur in warm $\left(>15^{\circ} \mathrm{C}\right)$ water which is above the main thermocline and similar to the central Stream in its physical properties (Wishner \& Allison in press). Therefore, the biomass increases are probably due to in situ processes and are not artifacts of sampling an abundant cold water fauna which could be present at the upper part of the thermocline $\left(15\right.$ to $\left.17^{\circ} \mathrm{C}\right)$ just above $200 \mathrm{~m}$. The MOCNESS vertical profiles (Fig. 3) show no such biomass feature near $200 \mathrm{~m}$.

The increased biological activity at fronts may be attributed to 2 main causes, which are not mutually exclusive. Fronts may experience an input of nutrients, which could enhance primary productivity, provide additional food for herbivores, and result in increased abundances of many organisms in the community. Alternatively, the water movement and structure at the front may interact with the behavior of zooplankton 
Table 3. Summary of previous results of biomass surveys in the western North Atlantic. The numbers are the median ratios of biomass in a region relative to the Sargasso Sea, as in Table 2 for the present study. N: not sampled. X: sampled only in this region

\begin{tabular}{|c|c|c|c|c|c|}
\hline \multirow[t]{2}{*}{ Study } & \multicolumn{3}{|c|}{ Region } & \multirow[t]{2}{*}{ Seasonality } & \multirow[t]{2}{*}{ Sampling method } \\
\hline & $\begin{array}{l}\text { Slope } \\
\text { water }\end{array}$ & $\begin{array}{l}\text { Gulf } \\
\text { Stream }\end{array}$ & $\begin{array}{l}\text { Sargasso } \\
\text { Sea }\end{array}$ & & \\
\hline Clarke (1940) & 4 & $\mathrm{~N}$ & 1 & $\begin{array}{c}\text { Yes - Slope } \\
\text { No-Sargasso }\end{array}$ & $\begin{array}{l}25 \& 50 \mathrm{~m} \text { oblique } \\
275 \& 800 \mathrm{~m} \text { oblique }\end{array}$ \\
\hline Moore (1949) & $\mathrm{N}$ & $\mathrm{N}$ & $x$ & Yes & $300 \mathrm{~m}$ oblique \\
\hline Fish (1954) & $\mathrm{N}$ & $\mathrm{N}$ & $\mathrm{X}$ & Irregular & $150 \mathrm{~m}$ oblique \\
\hline Bsharah (1957) & $\mathrm{N}$ & $\mathrm{x}$ & $N$ & Yes & $100 \& 600 \mathrm{~m}$ oblique \\
\hline Menzel \& Ryther (1961) & $\mathrm{N}$ & $\mathrm{N}$ & $X$ & Yes & $500 \mathrm{~m}$ oblique \\
\hline Grice \& Hart (1962) & 4 & 1 & 1 & $\begin{array}{c}\text { Yes - Slope } \\
\text { No-Sarg., GS }\end{array}$ & $200 \mathrm{~m}$ oblique \\
\hline Bé et al. (1971) & 4 & 1 & 1 & Yes & $300 \mathrm{~m}$ oblique \\
\hline Deevey (1971) & $\mathrm{N}$ & $\mathrm{N}$ & $\mathrm{X}$ & Yes & $500 \mathrm{~m}$ oblique \\
\hline Deevey \& Brooks (1971) & $\mathrm{N}$ & $\mathrm{N}$ & $x$ & Yes & $\begin{array}{l}2000 \mathrm{~m} \text { opening/closing } \\
500 \mathrm{~m} \text { intervals }\end{array}$ \\
\hline \multirow[t]{2}{*}{ Ortner et al. (1978) } & $3-15$ & $\mathrm{~N}$ & 1 & Yes & $\begin{array}{l}800 \mathrm{~m} \text { MOCNESS } \\
100 \mathrm{~m} \text { intervals }\end{array}$ \\
\hline & $2-15$ & $\mathrm{~N}$ & 1. & Yes & $\begin{array}{l}200 \mathrm{~m} \text { MOCNESS } \\
25 \mathrm{~m} \text { intervals }\end{array}$ \\
\hline Roman et al. (1985) & $1-3$ & $N$ & 1 & Yes & $\begin{array}{l}200 \mathrm{~m} \text { MOCNESS } \\
25 \mathrm{~m} \text { intervals }\end{array}$ \\
\hline Wiebe et al. (1985) & $1-3$ & 1 & 1 & $\begin{array}{l}\text { Yes - Slope, } \\
\text { Sarg. }\end{array}$ & $\begin{array}{l}1000 \mathrm{~m} \text { MOCNESS } \\
100 \& 25 \mathrm{~m} \text { intervals }\end{array}$ \\
\hline
\end{tabular}

advected to the frontal region and result in their concentration.

Increased primary productivity and phytoplankton biomass have been observed at fronts (e.g. Pingree et al. 1975, Fournier et al. 1977), and Lessard (1984) measured phytoplankton peaks at the north wall of the Gulf Stream. Zooplankton concentrations and abundances of planktivorous fish and seabirds may also be elevated in frontal regions (e.g. Bowman \& Esaias 1977, Haury et al. 1978, Wishner 1980a, Herman et al. 1981, Deibel 1985, Haney \& McGillivary 1985, Olson \& Backus 1985). Off the eastern United States coast south of Cape Hatteras, biomass peaks and organism aggregations related to frontal upwelling and eddies along the western edge of the Gulf Stream have been described (Atkinson et al. 1978, McClain et al. 1984, Paffenhöfer et al. 1984, Deibel 1985). However, this region is quite different from the north wall of the Gulf Stream offshore east of Cape Hatteras, because the Stream along the coast is topographically constrained by the shallow continental shelf, which strongly affects mixing processes, and is bordered by coastal shelf water rather than oceanic Slope Water.

Although we cannot differentiate between the causes of aggregations at the north wall front, we can use hydrographic and velocity data taken on the same cruises (Halkin 1984, Halkin \& Rossby 1985) to help interpret some of the biological observations. For example, in March 1982, there was a high concentra- tion of the diatom Thalassiosira partheneia at the north wall. The diatoms were encountered at 3 stations, 2 in the Slope Water (P8 and P7) and 1 at the north wall (P6), over a distance of $40 \mathrm{~km}$ on March 13 at the start of a north to south transect and again at the same stations on March 19 at the end of a south to north transect. Downstream velocity was approximately $10 \mathrm{~cm} \mathrm{~s}^{-1}$ at P8, $20 \mathrm{~cm} \mathrm{~s}^{-1}$ at P7, and $80 \mathrm{~cm} \mathrm{~s}^{-1}$ at $\mathrm{P} 6$ (Halkin 1984). Based on the probable continuous occurrence of the diatoms over the $6 \mathrm{~d}$ at a location (P6) where the current was moving $80 \mathrm{~cm} \mathrm{~s}^{-1}$ downstream, this patch could have been $415 \mathrm{~km}$ long. Although satellite observations have previously documented filaments of high-chlorophyll water over $100 \mathrm{~km}$ long at the western edge of the Gulf Stream in the Georgia Bight (McClain et al. 1984), there are no cloud-free Nimbus 7 coastal zone color scanner satellite images of the north wall location during the time of this cruise to check the dimensions of the diatom patch.

It is possible that an increased continuous nutrient input was sustaining a bloom of the diatom along the north wall at this time. During the cruise, the crossstream velocity direction was toward the south at $\mathrm{P} 8$, toward the north at P7, and toward the south at P6 (Halkin 1984). This indicates a divergence at $P 6$, which implies that upwelling was occurring, and Halkin (1984) found a shallow cold water intrusion here at this time. There is no evidence of an eddy or ring in the immediate vicinity (U.S. National Weather Service 
Oceanographic Analysis Charts for March 15 to 19, 1982).

Zooplankton biomass was also elevated at the north wall of the Gulf Stream during this cruise, possibly as a result of increased phytoplankton abundance persisting for several weeks. In the northwest African upwelling region. Thalassiosira partheneia forms large colonies (Elbrachter \& Boje 1978), which may disintegrate into single cells providing a good food source for copepods (Schnack 1983). Along the Georgia coast, copepods show a response to Stream-related upwelling events with a lag of about $3 \mathrm{wk}$ (Paffenhöfer 1980), and doliolids may respond in days (Deibel 1985). Alternatively, it is possible that advection concentrated both the zooplankton and phytoplankton independently in this same area.

The high abundances of salps and ctenophores seen at the north wall and adjacent Slope Water station in May 1983 were present on only one sampling date (May 10 to 11), and were gone from the entire upper $1000 \mathrm{~m}$ of the water column by May 19, when we returned to these stations. Salp patches have previously been observed in the Slope Water, including a station near the Gulf Stream (Grice \& Hart 1962, Wiebe et al. 1979), but apparently have not been associated directly with the north wall front. Large dense patches of gelatinous zooplankton are occasionally reported throughout the world's oceans (Omori \& Hamner 1982), and their association with unusually low concentrations of smaller zooplankton, as in our samples, has also sometimes been documented (Deibel 1985).

Either predation or food limitation may account for the low abundance of small zooplankton. For example, aggregations of ctenophores or other gelatinous carnivores can consume a high percentage of the smaller zooplankton present (Swanberg 1974, Omori \& Hamner 1982, Purcell 1983), and predation by Pleurobrachia pileus near the north wall may have reduced the standing stock of crustacean zooplankton during this cruise. An alternative explanation is that the salps, which are voracious herbivores (Alldredge \& Madin 1982), consumed most of the available phytoplankton food, so that other herbivorous zooplankton were unable to survive.

The vertical distributions of zooplankton biomass in the Gulf Stream are similar to other studies in the northwest Atlantic (Grice \& Hulsemann 1965, Deevey \& Brooks 1971, Ortner et al. 1978, 1980, Roman et al. 1985, Wiebe et al. 1985), and the overall decrease in zooplankton biomass from the surface to $1000 \mathrm{~m}$ agrees with general trends from many ocean regions (Grice \& Hulsemann 1965, Vinogradov 1968, Wishner 1980b). The similarity between integrated water column abundances $(0$ to $1000 \mathrm{~m}$ ) in the day and night (except at the north wall) indicates that diel differences in net avoidance are generally not a serious problem. Like
Wiebe et al. (1985), we observed a stronger diel vertical migration at our southern stations near and in the Sargasso Sea than at our more northern stations in the Slope Water and at the north wall. In the warm core of the Gulf Stream, the intensity of diel changes seems to be reduced, although day and night biomasses from the upper $200 \mathrm{~m}$ (in the year-long oblique tow sample set) are still significantly different.

Seasonal patterns observed in this study resemble those from other workers in the north Atlantic (summarized in Table 3). However, the presence of a seasonal cycle of zooplankton biomass in the Sargasso Sea has been debated (Table 3). We found no statistically significant seasonal cycle of zooplankton biomass in the Sargasso Sea, but we did find an apparent spring biomass increase in the Gulf Stream and at its north wall. Since our work extended for only $1 \mathrm{yr}$, it is not possible to establish the limits of variability in seasonal patterns or to differentiate critically between a seasonal pattern and other between-cruise fluctuations. A rigorous analysis would require the study of many complete yearly cycles.

The vertically stratified MOCNESS samples in conjunction with the Pegasus velocity profiles (Halkin 1984, Halkin \& Rossby 1985) can be used to examine the transport of zooplankton biomass in the Gulf Stream. Wishner \& Allison (in press) suggest that for copepods in the Gulf Stream, long distance downstream transport is most likely in the central core of the Stream and in the high velocity surface water near the north wall. Cross-stream transport along sloping isopycnals is most likely at depth below the oxygen minimum zone. At the surface, copepods may be mixed easily between the Gulf Stream and Sargasso Sea, but could be carried across the north wall front mainly by mesoscale events. Similar processes should apply to other zooplankton as well.

During both September and May, for example, there is a biomass peak in the upper $100 \mathrm{~m}$ across the Gulf Stream both day and night (Fig. 3), which accounts for 19 to $73 \%$ of the integrated 0 to $1000 \mathrm{~m}$ zooplankton biomass. Within the central Stream, the upper $100 \mathrm{~m}$ contains a mean proportion of $60 \%$ of the zooplankton biomass. Downstream velocities here exceed $100 \mathrm{~cm} \mathrm{~s}^{-1}$, and therefore it is likely that a large proportion of the total zooplankton biomass is being rapidly advected downstream.

Diel vertical migration may also affect the direction of zooplankton transport in the Gulf Stream (Wishner \& Allison in press). The deep daytime biomass peak (Fig. 3), which accounts for a mean of $25 \%$ (range: 11 to $50 \%$ ) of the total $1000 \mathrm{~m}$ biomass, extends to depths at which cross-stream transport along isopycnals occurs (Shaw \& Rossby 1984, Bower et al. 1985), and it is likely that the zooplankton are also being trans- 
ported cross-stream during the day. At night, much of the zooplankton migrates to shallower depths, with less chance of cross-stream mixing. In the central core of the Gulf Stream (100 to $400 \mathrm{~m}$ depth), where downstream transport is large and cross-stream transport small, zooplankton biomass is generally low (mean = $14 \%$ of the 0 to $1000 \mathrm{~m}$ total biomass). However, many animals travel into or through this region in diel migrations, and for these periods of time, they are subjected to extensive downstream transport. Thus, the amount of zooplankton biomass advected downstream may vary strongly with the diel cycle.

Seasonal cycles of surface water temperature may also affect the potential transport of zooplankton biomass. For example, in May 1983, the surface temperature difference between the Slope Water and Gulf Stream was $10 \mathrm{C}^{\circ}$, so it is unlikely that surface-limited zooplankton survived if carried across the north wall. However, in September 1982, when surface temperatures were similar (within $2 \mathrm{C}^{\circ}$ ) in the Slope Water and Stream, crossstream mixing was probably more successful.

\section{CONCLUSIONS}

(1) Zooplankton biomass is highest in the Slope Water, intermediate but more variable at the north wall of the Gulf Stream, and lowest in the central Stream and Sargasso Sea.

(2) The north wall front of the Gulf Stream is a region in which zooplankton and phytoplankton biomass can be elevated considerably over that of the central Stream despite similarities in the physical properties of the surface water in the 2 regions.

(3) There is an apparent seasonal pattern in zooplankton biomass in the Slope Water, at the north wall of the Gulf Stream, and in the central Stream, with a maximum in late spring and early summer and a minimum in the autumn. No seasonal biomass pattern was detected in the Sargasso Sea.

(4) The amount and direction of zooplankton biomass transport varies with location in the Stream. The vertical distribution of zooplankton biomass, including diel changes related to vertical migration, interacts with the horizontal and vertical structure of the velocity field. Downstream transport of biomass is probably greatest in the surface water, because both biomass and water velocites are high. Cross-stream transport is probably highest below the oxygen minimum zone and at the southern edge of the Gulf Stream.

Acknowledgements. We thank $\mathrm{H}$. T Rossby for providing us with sampling time and assistance during his cruises and for providing hydrographic and velocity data from the Pegasus program. J. Wormuth lent us the MOCNESS net system and helped extensively at sea. E. Swift lent us the small open plankton net. D. Dorson, J. Fontaine, W Hahn, and the URI marine technicians provided essential technical assistance. Many students, especially E. Buskey, K. Kelly, M. Hallisey, and $\mathrm{L}$. Beatty helped with sampling at sea, and $\mathrm{D}$. Halkin processed and interpreted the velocity data. We also thank the captains and crews of the R/V Endeavor and R/V Cape Hatteras for their assistance. H. T. Rossby, N. G. Hairston Jr., T. A. Napora, and W. P. Sousa reviewed an earlier version of the manuscript.

A portion of this work is part of an M.Sc. thesis by S. K. Allison at the University of Rhode Island. The Graduate School of Oceanography at the University of Rhode Island provided funds to $\mathrm{K}$. Wishner for the research, and S. K. Allison was supported by a University of Rhode Island graduate assistantship and fellowship. Ship time was funded by NSF grant OCE 83-10833 and ONR grant N00014-81-C-0062 to H. T. Rossby.

\section{LITERATURE CITED}

Alldredge, A. L., Madin, L. P. (1982). Pelagic tunicates: Unique herbivores in the marine plankton. Bioscience 8 : 655-663

Angel, M. V. (1979). Zoogeography of the Atlantic Ocean. In: Van der Spoel, S., Pierrot-Bults, A. C. (ed.) Zoogeography and diversity of plankton. Halstead, New York, p. 168-190

Atkinson, L. P., Paffenhöer, G.-A., Dunstan, W. M. (1978). The chemical and biological effect of a Gulf Stream intrusion off St. Augustine, Florida. Bull. mar. Sci. 28: 667-679

Backus, R. H., Craddock, J. E., Haedrich, R. L., Robison, B. H. (1977). Atlantic mesopelagic zoogeography. In: Gibbs, R. H. (ed.) Fishes of the western North Atlantic. Mem. Sears Fdn mar. Res. 1, part 7, p. 266-287

Bé, A. W. H., Forns, J. M., Roels, O. A. (1971). Plankton abundance in the North Atlantic Ocean. In: Costlow, J. D., Jr. (ed.) Fertility of the sea, Vol. 1 Gordon and Breach, New York, p. 17-50

Beers, J. R. (1976). Determination of zooplankton biomass. In: Steedman, H. F. (ed.) Zooplankton fixation and preservation. Unesco Press, Paris, p. 35-84

Bower, A. S., Rossby, H. T., Lillibridge, J. L. (1985). The Gulf Stream - barrier or blender? J. phys. Oceanogr. 15: 24-32

Bowman, M. J., Esaias, W E. (ed.) (1977). Oceanic fronts in coastal processes. Springer-Verlag, Berlin

Bsharah, L. (1957). Plankton of the Florida Current. V. Environmental conditions, standing crop, seasonal and diurnal changes at a station forty miles east of Miami. Bull, mar Sci. Gulf. Caribb. 7: 201-251

Clarke, G. L. (1940). Comparative richness of zooplankton in coastal and offshore areas of the Atlantic. Biol. Bull. mar. biol. Lab., Woods Hole 78: 226-255

Deevey, G. B. (1971). The annual cycle in quantity and composition of the zooplankton of the Sargasso Sea off Bermuda. 1 . The upper $500 \mathrm{~m}$. Limnol Oceanogr. 16: 219-240

Deevey, G. B., Brooks, A. L. (1971). The annual cycle in quantity and composition of the zooplankton of the Sargasso Sea off Bermuda. II. The surface to $2000 \mathrm{~m}$. Limnol. Oceanogr. 16: 927-943

Deibel, D. (1985). Blooms of the pelagic tunicate, Dolioletta gegenbauri: Are they associated with Gulf Stream frontal eddies? J. mar Res. 43: 211-236

Elbrachter, M., Boje, R. (1978). On the ecological significance of Thalassiosira partheneia in the northwest African upwelling area. In: Boje, R., Tomczak, M. (ed.) Upwelling ecosystems. Springer-Verlag, Berlin, p. 24-31 
Fish, C. J. (1954). Preliminary observations on the biology of boreoarctic and subtropical zooplankton populations. In: Symposium on marine and freshwater plankton in the Indo-Pacific, Bangkok. Diocesan Press, Madras, p. 3-9

Fofonoff, N. P. (1981). The Culf Stream system. In: Warren, B. A., Wunsch, C. (ed.) Evolution of physical oceanography. MIT Press, Cambridge, Massachusetts, p. 112-139

Fournier, R. O., Marra, J., Bohrer, R., Van Det, M. (1977). Plankton dynamics and nutrient enrichment of the Scotian Shelf. J. Fish. Res. Bd Can. 34: 1004-1018

Grice, G. D., Hart, A. D. (1962). The abundance, seasonal occurrence, and distribution of epizooplankton between New York and Bermuda. Ecol. Monogr. 32: 287-309

Grice, G. D., Hulsemann, K. (1965). Abundance, vertical distribution, and taxonomy of calanoid copepods at selected stations in the northeast Atlantic. J. Zool., Lond. 146: 213-262

Halkin, D. (1984). The structure and transport of the Gulf Stream at $73^{\circ} \mathrm{W}$. M.Sc. thesis, Univ. of Rhode Island

Halkin, D., Rossby, T (1985). The structure and transport of the Gulf Stream at $73^{\circ} \mathrm{W}$. J. phys. Oceanogr. 15: $1439-1452$

Haney, J. C., McGillivary, P. A. (1985). Midshelf fronts in the South Atlantic Bight and their influence on seabird distribution and seasonal abundance. Biol. Oceanogr. 3 . $401-430$

Haury, L. R., McGowan, J. A., Wiebe, P. H. (1978). Patterns and processes in the time-space scales of plankton distribution. In: Steele, J. H. (ed.) Spatial patterns in plankton communities. Plenum Press, New York, p. 277-327

Herman, A. W., Sameoto, D. D., Longhurst, A. R. (1981). Vertical and horizontal distribution patterns of copepods near the shelf break south of Nova Scotia. Can. J. Fish. Aquat. Sci. 38: 1065-1076

Lessard, E. J. (1984). Oceanic heterotrophic dinoflagellates: distribution, abundance, and role as microzooplankton Doctoral dissertation. Univ. of Rhode Island

McClain, C. R., Pietrafesa, L. J., Yoder, J. A. (1984). Observations of Gulf Stream-induced and wind-driven upwelling in the Georgia Bight using ocean color and infrared imagery. J. geophys. Res. 89: 3705-3723

Menzel, D. W., Ryther, J. H. (1961). Zooplankton in the Sargasso Sea off Bermuda and its relation to organic production. J. Cons. perm. int. Explor. Mer 26: 250-258

Moore, H. B. (1949). The zooplankton of the upper waters of the Bermuda area of the North Atlantic. Bull. Bingham oceanogr. Coll. 12; 1-97

Nautical Almanac Office, U.S. Naval Observatory (1981, 1982, 1983). The nautical almanac for the year 1981, 1982 1983. U.S. Govt Printing Office, Washington D.C.

Olson, D. B., Backus, R. H. (1985). The concentrating of organisms at fronts: A cold-water fish and a warm-core Gulf Stream ring. J. mar Res. 43: 113-137

Omori, M., Hamner, W. M. (1982). Patchy distribution of zooplankton: Behavior, population assessment, and sampling problems. Mar. Biol. 72: 193-200

Ortner, P. B., Wiebe, P. H., Haury, L., Boyd, S. (1978). Variability in zooplankton biomass distribution in the northern Sargasso Sea: the contribution of Gulf Stream cold core rings. Fish. Bull. U.S. 76: 323-334

Ortner, P. B., Wiebe, P. H., Cox, J. L. (1980). Relationships between oceanic epizooplankton distributions and the seasonal deep chlorophyll maximum in the northwestern Atlantic Ocean. J. mar. Res. 38: 507-531

Paffenhöfer, G.-A. (1980). Zooplankton distribution as related to summer hydrographic conditions in Onslow Bay, North Carolina. Bull. mar. Sci 30: 819-832

Paffenhöfer, G.-A., Wester, B. T., Nicholas, W D. (1984) Zooplankton abundance in relation to state and type of intrusions onto the southeastern United States shelf during summer. J. mar. Res. 42: 995-1017

Pingree, R. D., Pugh, P. R., Holligan, P. M., Forster, G. R. (1975). Summer phytoplankton blooms and red tides along tidal fronts in the approaches to the English Channel Nature, Lond. 258: 672-677

Purcell, J. E. (1983). Digestion rates and assimilation efficiencies of siphonophores fed zooplankton prey. Mar. Biol. 73 . $257-261$

Ring Group (1981). Gulf Stream cold-core rings: their physics chemistry, and biology. Science 212: 1091-1100

Roman, M. R., Gauzens, A. L. Cowles, T. J. (1985). Temporal and spatial changes in epipelagic microzooplankton and mesozooplankton biomass in warm-core Gulf Stream ring 82-B. Deep Sea Res. 32: 1007-1022

Scheltema, R. (1971). Larval dispersal as a means of genetic exchange between geographically separated populations of shallow-water benthic marine gastropods. Biol. Bull mar. biol. Lab., Woods Hole 140: 284-322

Schnack, S. B. (1983). On the feeding of copepods on Thalassiosira partheneia from the northwest African upwelling area. Mar. Ecol. Prog. Ser 11:49-53

Shaw, P. T., Rossby, H. T. (1984). Towards a Lagrangian description of the Gulf Stream. J. phys. Oceanogr. 14 $528-540$

Sokal, R. R., Rohlf, F. J. (1981). Biometry. 2nd edn. W H. Freeman Co., San Francisco

Spain, P. F., Dorson, D. L., Rossby, H. T. (1981). PEGASUS: a simple, acoustically tracked, velocity profiler. Deep Sea Res. 28 A: $1553-1567$

Stepien, J. C. (1980). The occurrence of chaetognaths, pteropods and euphausiids in relation to deep flow reversals in the Straits of Florida. Deep Sea Res. 27A: 987-1011

Stommel, H. (1965). The Gulf Stream. 2nd edn. Univ. of California Press, Berkeley

Swanberg, N. (1974). The feeding behavior of Beroe ovata. Mar. Biol. 24: 69-76

Vinogradov, M. E. (1968). Vertical distribution of the oceanic zooplankton. Academy of Sciences of the U.S.S.R., Institute of Oceanography, translated from Russian by Israel Program for Scientific Translations, Jerusalem, 1970

Wiebe, P. H., Burt, K. H., Boyd, S. H., Morton, A. W. (1976). A multiple opening/closing net and environmental sensing system for sampling zooplankton. J. mar. Res. 34: 313-326

Wiebe, P. H., Madin, L. P., Haury, L. R., Harbison, G. R., Philbin, L. M. (1979). Diel vertical migration by Salpa aspera and its potential for large-scale particulate organic matter transport to the deep sea. Mar. Biol. 53: 249-255

Wiebe, P. H., Flierl, G. R., Davis, C. S., Barber, V., Boyd, S. H. (1985). Macrozooplankton biomass in Gulf Stream warmcore rings: spatial distribution and temporal changes. J geophys. Res. 90: 8885-8901

Wishner, K. F. (1980a). Near-bottom sound scatterers in the Ecuador Trench. Deep Sea Res. 27A: 217-223

Wishner, K. F. (1980b). The biomass of the deep-sea benthopelagic plankton. Deep Sea Res. 27A: 203-216

Wishner, K. F., Allison, S. K. (in press). The distribution and abundance of copepods in relation to the physical structure of the Gulf Stream. Deep Sea Res.

Worthington, L. V. (1976). On the North Atlantic circulation. Johns Hopkins Univ. Press, Baltimore 